\title{
SHORT NOTE \\ A GLADIOLUS WITH LINKS TO ST ANDREWS AND EDINBURGH
}

\section{Robert J. Mitchell ${ }^{1}$}

The University of St Andrews Botanic Garden was founded by Dr John Hardie Wilson (1858-1929) (Fig. 1) in 1889. Dr. Hugh Cleghorn, Charles Howie and his assistant, Thomas Berwick, were among those present. In the University of St Andrews Library archives there is a collection of Wilson's photographs and records of the Botanic Garden over a ten-year period showing a wide diversity of plants laid out according to the Bentham and Hooker system of classification, with 828 species planted in 78 order beds.

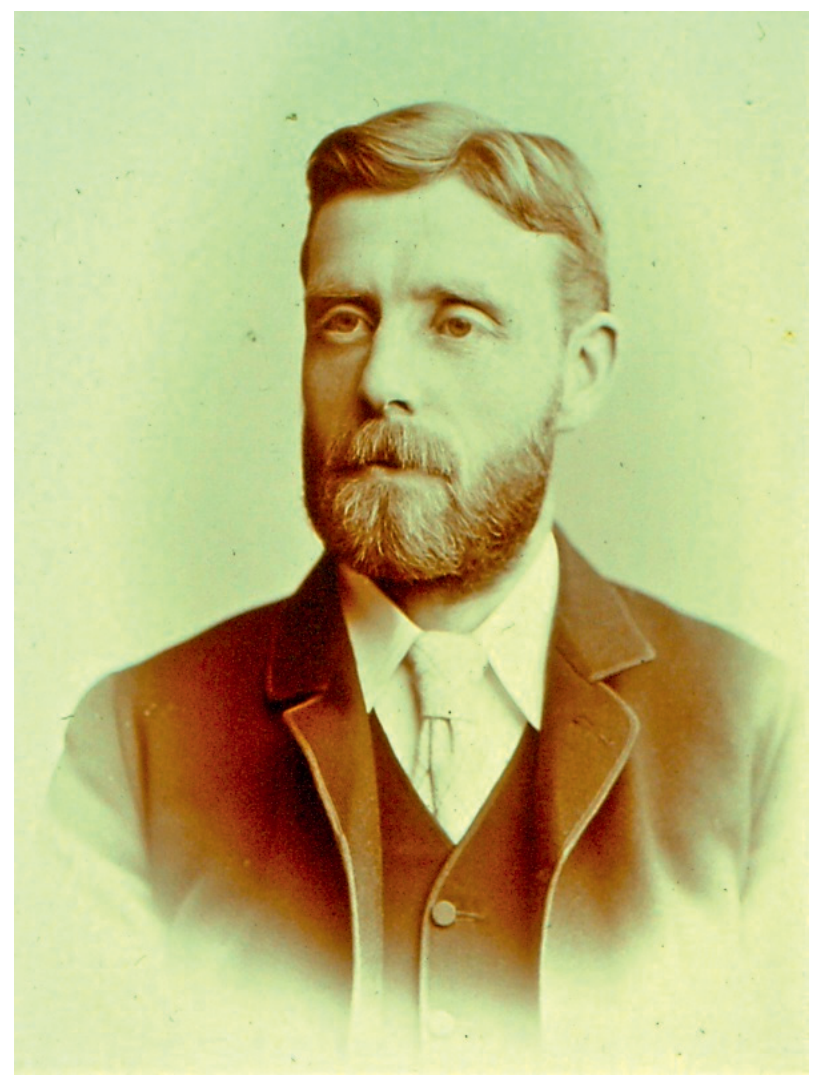

Fig. 1 Dr John Wilson. Photo: Image number mS37103-2-19v, courtesy of University of St Andrews Library.

1. Robert J. Mitchell is Honorary Curator at the University of St Andrews Botanic Garden. Address: Kingscroft, Elie, Fife KY9 1BY.

Email: kingscroft@care4free.net 
The Dr John Wilson archives in the University of St Andrews Library also contain photographs and records he made during his period at the Royal Botanic Garden Edinburgh (RBGE) (Figs 2 \& 3). The Scotsman reported that John Wilson "was appointed by the Treasury to be Curator of the Herbarium and Library at the Royal Botanic Garden in Edinburgh" (The Scotsman, 1890), a position that he held for four years. Photographs include the original Rock Garden, the Order Beds with the top of John Hope's memorial to Linnaeus visible and the view from the Palm House to the south. Also included is a booklet containing a list of herbaceous plants growing at RBGE in 1893.

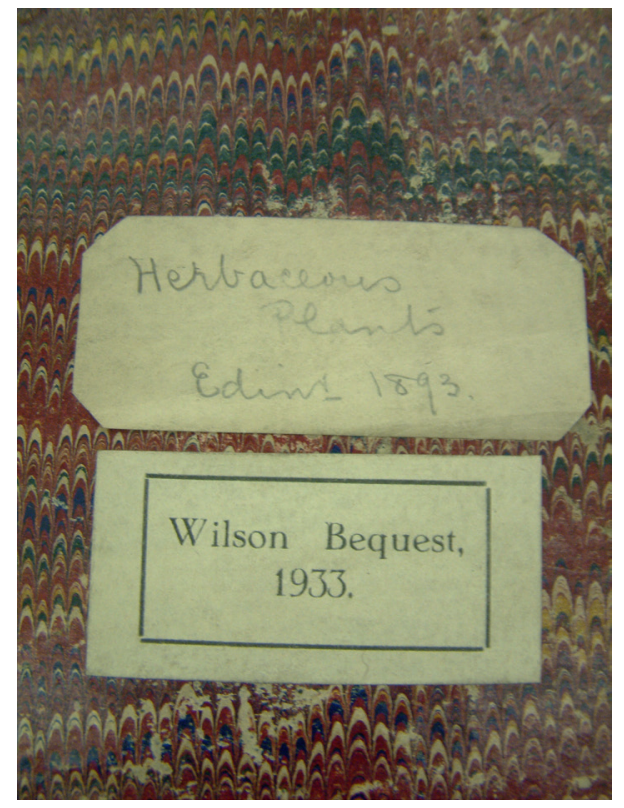

Fig. 2 Cover of the Wilson bequest in University of St Andrews Library. Photo: Robert Mitchell.

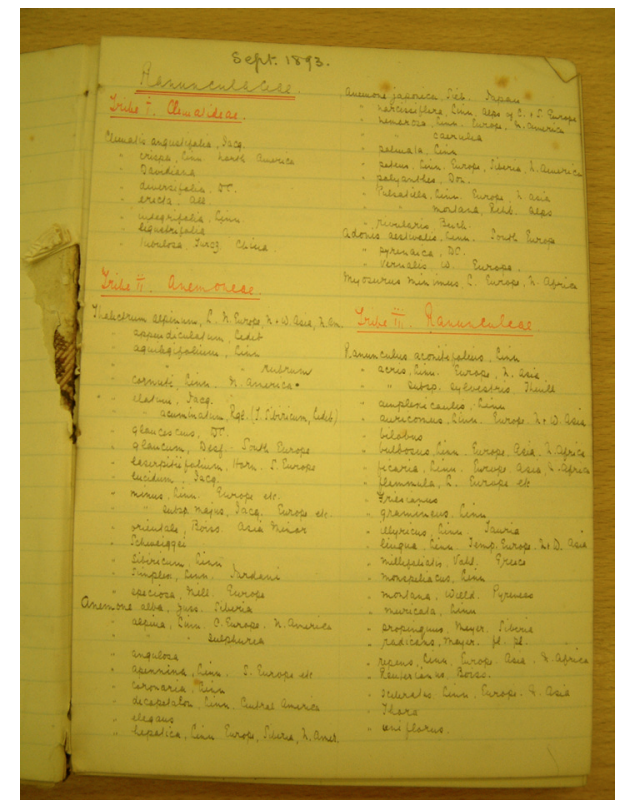

Fig. 3 Photograph of extract from notes of herbaceous plants made by Dr John Wilson at RBGE in 1893. Photo: Robert Mitchell.

In 1894 he was appointed Lecturer of Botany at Yorkshire College, which was later to become Leeds University. He founded the botanic garden there and returned to St Andrews in 1899 to lecture in agriculture. With his father, James Wilson (18351905), who owned Greenside Nursery in St Andrews, he continued his plant-breeding programmes on blight-resistant potatoes, cereals, fodder crops and a wide assortment of decorative plants, some of which are still available today. Potato 'The Bishop' and Passiflora 'St Regulus' are two of them. The new decorative plants he raised were displayed at the Royal Caledonian Horticultural Society shows in Edinburgh, and their trade stand exhibit in September 1905 was awarded a Gold Medal.

One of the photographs in the archives is of Tritonia wilsonii. It was named by John Gilbert Baker (1834-1920) in 1886 in the Gardeners' Chronicle (Baker, 1888) 
and authenticated in Flora Capensis in 1897 (Baker, 1897). There was subsequently a name change and the plant, with authorities, is now Gladiolus wilsonii (Baker) Goldblatt and J.C. Manning (Goldblatt \& Manning, 1998).

Alexander Wilson (1860-1942), the youngest of the three Wilson brothers, sent a collection of bulbs back to St Andrews from Port Elizabeth in Eastern Cape Province, South Africa in 1885. They flowered the following year at the Greenside Nursery in St Andrews. Specimens (herbarium references K000320934 and K000257287 respectively) were sent by John Wilson to Kew where Baker discovered that they were new species and named them Tritonia wilsonii and Albuca corymbosa. It is not clear whether the Tritonia was named for Alexander or for John, or perhaps both as Goldblatt and Manning suggest (Goldblatt and Manning, 1998).

Alexander emigrated to the USA and worked for the San Francisco branch of the Liverpool-based firm of importers Balfour, Guthrie and Company from 1886. It is highly likely that coming from St Andrews, he was a founding member of San Francisco Golf Club in 1895 along with senior directors of this firm.

According to Manning, Goldblatt and Snijman, Gladiolus wilsonii grows in grassy areas in the East Cape between Humansdorp and Transkei (Manning et al., 2002). This is the summer rainfall area where it flowers in October and November. It is an elegant plant with a spike of four to twelve fragrant flowers. They are white to cream in colour and often flushed pink to purple on the outer tepal (Fig. 4). The anthers are lavendercoloured and are covered by the hood.

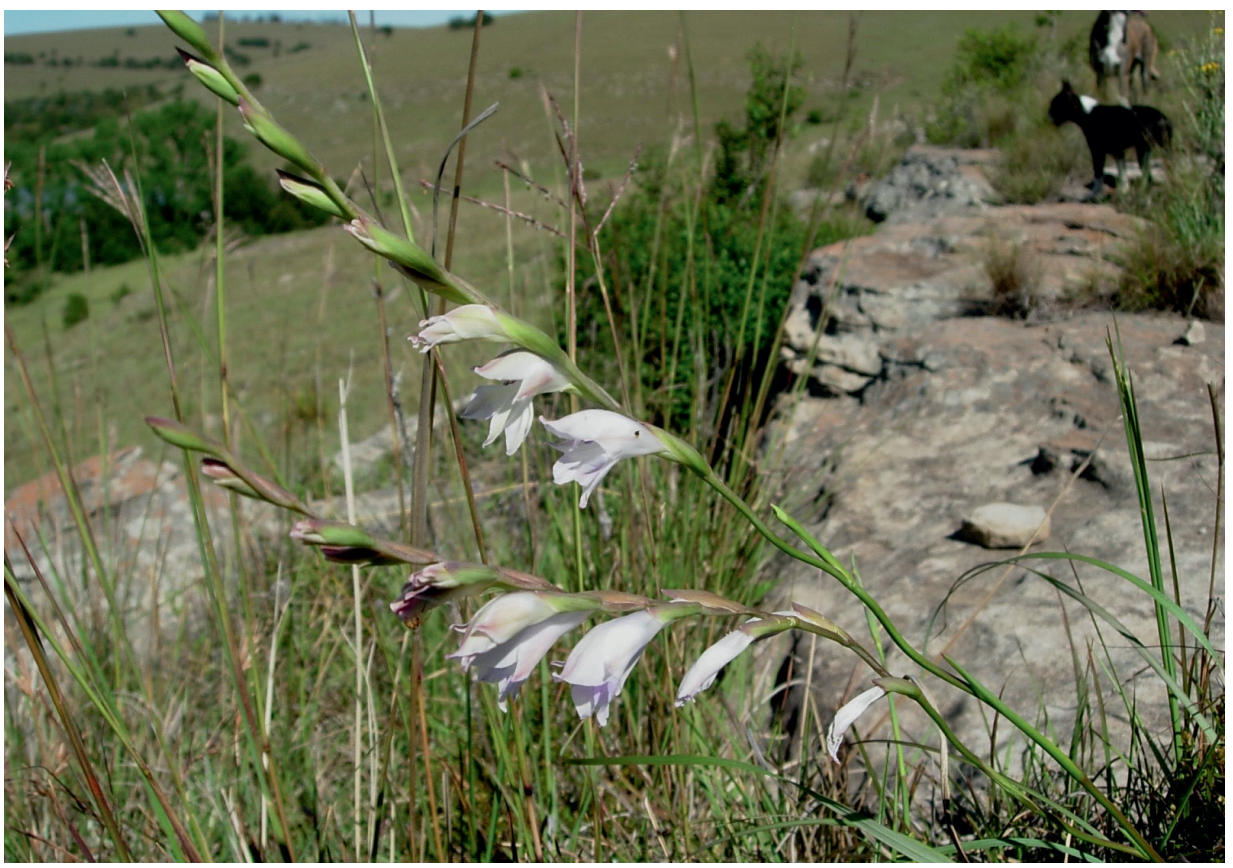

Fig. 4 Gladiolus wilsonii in the Eastern Cape, South Africa. Photo: Copyright of Cameron McMaster. 
After many years I have at last been able to obtain seed of Gladiolus wilsonii from a wild population growing at Middledrift Farm, belonging to Rhoda and Cameron McMaster, in the Cathcart region of the Eastern Cape. The seed sent by Cameron McMaster has been shared between St Andrews Botanic Garden and RBGE, because of the link to John Wilson and the fact that he worked for four years at RBGE. So in a few years we hope to have flowering plants to match the photograph that Wilson took in his time at RBGE.

\section{ACKNOWLEDGEMENTS}

I am grateful to the University of St Andrews Library for their help and for the use of their material and to Cameron McMaster for sending and permitting the use of the Gladiolus photograph (Fig. 4). Most of the Wilson family history has been extracted from Macdonald (1984).

\section{REFERENCES}

BAKER, J.G. (1988). Gardeners' Chronicle July 1988. XXVI, 38.

BAKER, J.G. (1897). Tritonia wilsonii, in THISELTON-DYER, W. (ed.). Flora Capensis VI. Royal Botanic Gardens, Kew, 125-6.

GOLDBLATT, P. \& MANNING, J. (1998). Gladiolus of Southern Africa, 206-7, plate 78. Fernwood Press, Cape Town.

MACDONALD, J.A. (1984). Plant Science and Scientists in St Andrews: up to the middle of the 20th century. Privately published by the author.

MANNING, J. (2001). South Africa Wild Flower Guide, 11 - East Cape. Botanical Society of South Africa, Cape Town, 82, 94, 100.

MANNING, J., GOLDBLATT, P. \& SNIJMAN, D.A. (2002). The Color Encyclopedia of Cape Bulbs. Timber Press, Portland, OR.

MCMASTER, C. (2010). Available online: www.africanbulbs.com (accessed April 2010).

THE SCOTSMAN (1890). 14 October.

WILSON, J. (1888). On the adaptation of Albuca corymbosa Baker and Albuca juncifolia Baker to insect pollination. Transactions of the Botanical Society of Edinburgh, XVI, 36-370. 